\title{
Питання психології
}

УДК 159.924.7: 316.4

DOI: $10.33099 / 2617-6858-20-56-3-5-13$

Березовська Л. І. кандидат психологічних наук, дочент, Національний університет «Львівська політехніка» https://orcid.org/0000-0002-5972-7883

Ямчук Т. Ю. кандидат психологічних наук, Мукачівський державний університет.

https://orcid.org/0000-0003-0392-2249

\section{ПСИХОЛОГІЯ МІЖОСОБИСТІСНИХ ВЗАЄМИН ПОДРУЖНЬОЇ ПАРИ}

У статті представлено результати теоретичного та емпіричного дослідження міжсособистісних взаємин подружсньої пари. Визначено, що найбільш благополучними є ті сім'ї, які мають менший стаж подружнього життя. Задоволеність шлюбом залежить від особливостей сімейного оточення, від спілкування та взаємодії у конфлікті, від иіннісних орієнтаиій. У парах досліджуваних зі значним стажем подружніх взаємовідносин кореляиійні зв'язки є більш сильними та значимими.

Ключові слова: міжособистісні взаємини; подружсні пари; задоволеність шлюбом; конфліктна взаємодія; иіннісні орієнтаиії.

Актуальність дослідження.

Сьогодні через соціальні, економічні, культурні, політичні виклики відбуваються значні зміни у сімейних взаєминах. Інститут сім'ї особливо у молодих сім'ях зазнає постійної трансформації. Однак сімейні стосунки залишаються полем цікавості не тільки самих членів подружньої пари, родичів, дітей, батьків, а і наукової спільноти.

Проблеми дослідження міжособистісних взаємин, типів сімейної взаємодії висвітлено в дослідженнях Т.В. Андрєєвої, О.А. Карабанової, В.І. Зацепіна, Л.М. Бучинської, В.Н. Дружиніна та ін.. [3; 4]; питаннями задоволеності стосунками і сім'ї, сімейної стабільності, міжособистісного сприйняття подружжям, сумісності партнерів розкрито у працях Ю. Є. Альошиної, В.А. Сисенко, М.М. Обозова, А.М. Обозової [1]. К. Роджерс запропонував понятяя подружності та зазначав, що основою успішних взаємин у сім'ї $\epsilon$ емоційний зв'язок партнерів [8]. Етапи розвитку емоційно-близьких взаємин у сім'ї, універсальну форму подружньої взаємодії, яка передбачає взаємопорозуміння партнерів та задоволеність сімейними стосунками розглядав Н. Пезешкіан [6].

Метою статті виступає висвітлення психологічних особливостей подружньої пари залежно від стажу сімейного життя.
Міжособистісні взаємини в сімейних пар було визначено за рядом інструментальних методик. А саме: тестом-опитувальником «Задоволеність шлюбом» (В. Столін, Т. Романова, Г. Бутенко), методиками «Характер взаємодії подружжя в конфліктних ситуаціях», «Шкала сімейного оточення», «Діагностика реальної структури ціннісних орієнтацій особистості С.С. Бубнова», опитувальником «Особливості спілкування між подружжям» Ю.С. Альошиної, Л.Я. Гозман, Е.M. Дубровської. [2; 5; 7] Опис здійснено на основі використання методів математичної статистики: порівняльний (критерій НКраскала-Уоллеса) та кореляційний аналіз. Дослідження міжособистісних взаємин подружжя здійснено з сімейними парами, що проживають в Закарпатській області. В опитуванні взяло участь 43 сімейні пари (16 пар зі стажем подружнього життя до 3 років, 15 пар стаж 3-10 років та 12 пар - стаж проживання у шлюбі більше 10 років).

Згідно критеріїв опитувальника «Задоволеність шлюбом» (В. Столін, Т. Романова, Г. Бутенко) межі показників знаходяться на відрізку від 0 до 48 балів. Середні значення груп досліджуваних за даним опитувальником представлено в таблиці 1. 


\section{Питання психології}

Таблиця 1

Результати тесту-опитувальника «Задоволеність шлюбом (В. Столін, Т. Романова, Г. Бутенко).

\begin{tabular}{|c|c|c|c|c|c|}
\hline & Стаж & Кількість пар & Mean & Std. Deviation & Asymp. Sig. \\
\hline 1 група & $1-3$ p. & 16 & 30,56 & 6,12 & 0,000 \\
\cline { 1 - 4 } 2 група & $3-10$ p. & 15 & 27,90 & 3,48 & \\
\hline 3 група & Більше 10 p. & 12 & 23,17 & 3,70 & \\
\hline
\end{tabular}

Благополучними є ті сім'ї, які мають стаж сімейного життя від 1 до 3 років (Хсер. $=30,56, \sigma=6,12)$, до перехідних відносяться ті, сім'ї, що живуть у шлюбі від 3 до 10 років (Xсер. $=27,90, \sigma=3,48)$ та до неблагополучних відносяться ті, що разом проживають більше 10 років (Хсер. $=23,17, \sigma$ $=3,70)$. Ці відмінності між групами визначено на статистично значимому рівні за критерієм Н-Краскала-Уоллеса.

Отже, найбільш благополучними $€$ ті сім'ї, які мають менший стаж подружнього життя. Очевидно, почуття які $\epsilon$ між подружжям $\epsilon$ основою їхнього задоволення один одним та сімейним життям.

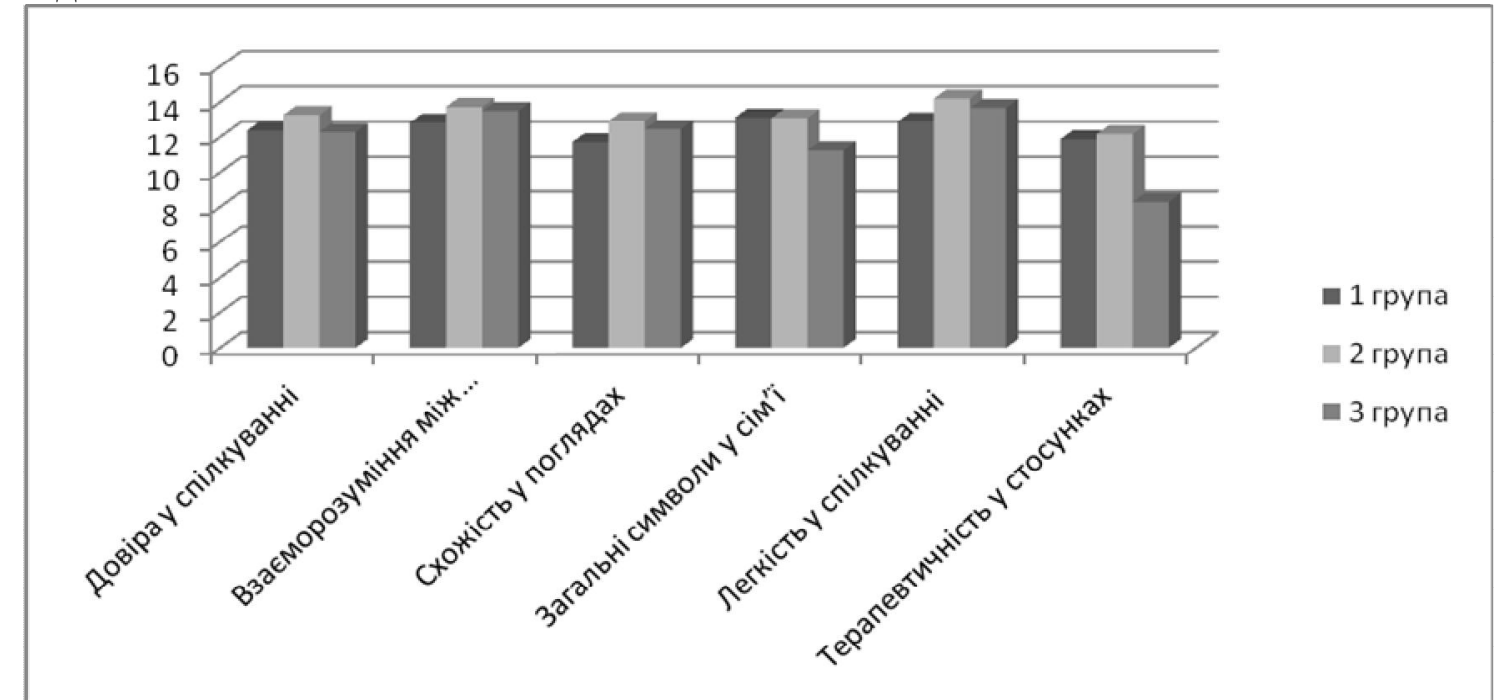

подружжям (довіра у спілкуванні, взаєморозуміння між подружжям, схожість у поглядах, загальні символи сім'ї, легкість у спілкуванні та психотерапевтичність у спілкуванні) ми дослідили за опитувальником «Особливості спілкування між подружжям» Ю.С. Альошиної, Л.Я. Гозман, Е.M. Дубровської. Згідно інтерпретації методики чим більше числове значення, тим більш теплішим, глибшим $\epsilon$ спілкування). Отримані дані представлено на рисунку 1.

Рис. 1. Результати опитувальника «Особливості спілкування між подружжям» Ю.С. Альошиної, Л.Я. Гозман, Е.М. Дубровської. 10 років.

Примітка: стаж подружнього життя: 1 група - до 3-ох років, 2 група - 3-10 років, 3 група - більше

Середні значення за п’ятьма шкалами не $\epsilon$ рівними (див. рис. 1), вони відрізняються у груп, але тільки за однією шкалою «терапевтичність стосунків» $є$ відмінності на статичному рівні за критерієм Н-КраскалаУоллеса. Найвищі показники у групі зі стажем сімейного життя від 3 до 10 років (Хсер. $=12,17, \sigma=5,16)$, трохи нижчі у групі подружжя яке живе разом не більше 3-ох років (Хсер. $=11,88, \sigma=5,22)$, найнижчі у того подружжя, яке проживає разом більше ніж 10 років (Хсер. $=8,29, \sigma=2,99$ ). Щодо інших шкал, то група, що має стаж подружнього життя 3-10 років має вищі показники довіри у спілкуванні, взаєморозуміння між подружжям, схожість у поглядах та легкість у спілкуванні.

Отже, особливостями подружнього спілкування $\epsilon$ те, що найменш «терапевтично» проходить спілкування у сім’ї, подружжя якої проживає разом більше, ніж 10 років.

Відносини 3 родичами і друзями, питання, пов'язані 3 вихованням дітей, прагнення до автономії, порушення рольових очікувань, неузгодженість норм поведінки, домінування одним із подружжя, прояв ревнощів, ставлення до грошей ми дослідили 


\section{Питання психології}

за методикою «Характер взаємодії подружжя в конфліктних ситуаціях». Згідно інтерпретації методики величина отриманих чисел свідчить про активність або пасивність при подружніх конфліктах. Негативне значення індексу говорить про негативну реакцію респондента в конфліктних ситуаціях, позитивні - про позитивні реакції. Значення, близькі до 1 (або до -1) підкреслюють пасивний характер поведінки при сімейних непорозуміннях, а близькі до 2 (або до -2) говорять про активну позицію в даній ситуації. Чим ближче значення загального індексу до -2 , тим більш конфліктний характер носить взаємодія подружжя. Отримані даних наведено на рисунку 2.

За 5 шкалами відмінності між середніми значеннями спостерігаються на статистичному рівні (за критерієм НКраскала-Уоллеса). Так, у конфліктних ситуаціях відносини 3 родичами і друзями позитивно та більш активно вибудовують ті подружжя, стаж сімейного життя у яких від 3 до 10 років (Xсер. $=0,30, \sigma=0,41)$. Щодо інших груп, то ті, хто має стаж подружнього життя більше 10 років вибудовують пасивно та негативно (Хсер. $=-0,13, \sigma=0,67)$, а ті, хто перебувають у подружніх стосунках до 3 років - пасивно та позитивно (Xсер. $=0,15, \sigma$ $=1,01)$.

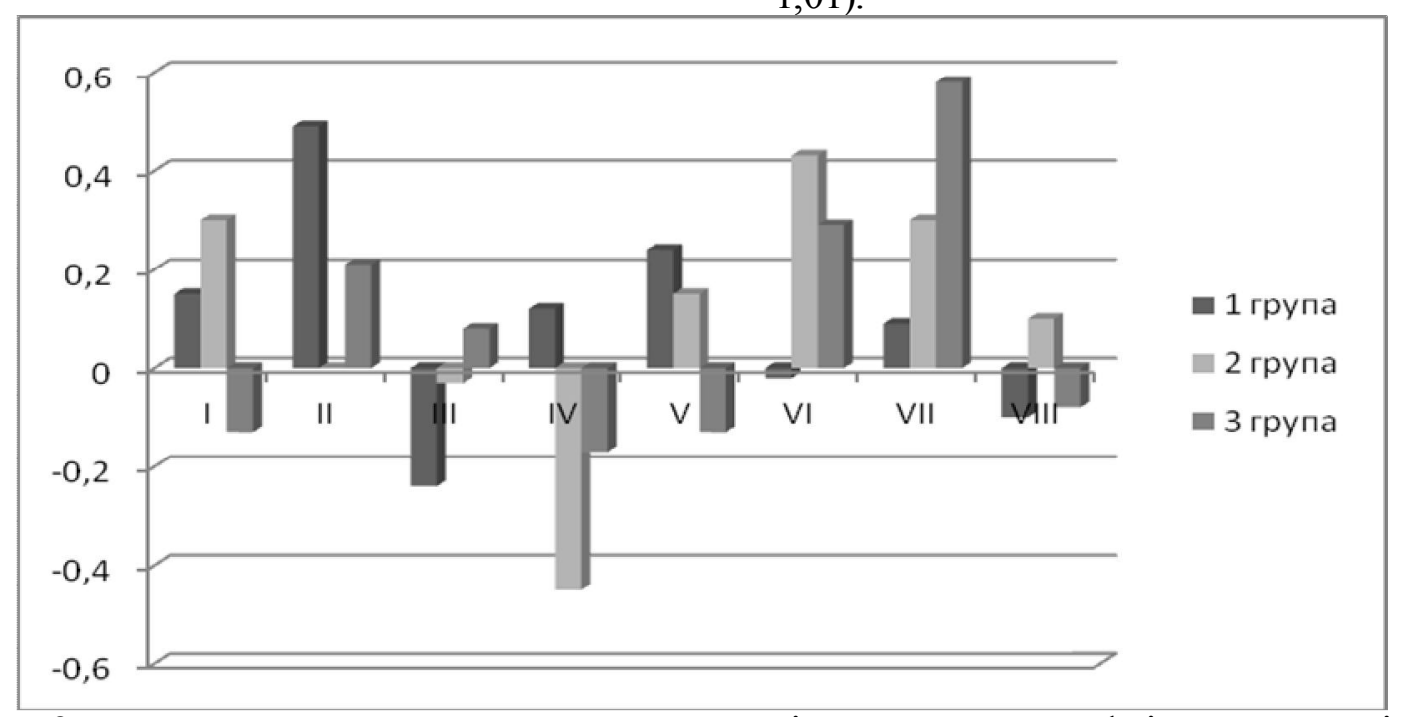

Рис. 2. Результати методики «Характер взаємодії подружжя в конфліктних ситуаціях».

Примітка:

1. шкали: I - відносини з родичами і друзями, II - питання, пов'язані з вихованням дітей, III прагнення до автономії, IV - порушення рольових очікувань, V - неузгодженість норм поведінки, VI домінування одним із подружжя, VII - прояв ревнощів, VIII - ставлення до грошей.

2. стаж подружнього життя: 1 група - до 3-ох років, 2 група - 3-10 років, 3 група - більше 10 років.

Питання, що стосуються виховання дітей більш позитивно та активно вирішують подружжя з сімейним стажем до 3 років (Хсер. $=0,49, \sigma=0,38)$, в інших групах ці показники є нижчими (Xсер. = $0,21, \sigma=0,58$ - група зі стажем більше 10 років та Хсер. $=0, \sigma=0,72-$ група, що разом проживає 3-10 років). В конфліктах, що стосуються порушень рольових очікувань, то знову ж найактивніше та негативно це проявляється в тій же групі опитаних (3-10 років) $($ Хсер. $=-0,45, \sigma=0,67)$, в групі зі стажем подружнього життя більше 10 років також у даному питання пов'язано 3 негативними емоціями (Xсер. $=-0,17, \sigma=$ $0,64)$, але більш спокійно, а в групі до 3 років спокійно та 3 позитивними емоціями $($ Хсер. $=0,12, \sigma=0,57)$. Найбільш позитивно

та активно вирішують неузгодженість норм поведінки, що проявляються у конфліктах, ті сімейні пари, які живуть найкоротший час у шлюбі (Xсер. $=0,24, \sigma=0,48$ ), менш активно група 3 3-10 роками стажу подружнього життя (Xсер. $=0,15, \sigma=0,76)$ та найбільш негативні емоції в даному питанні проявляють ті, хто проживає у шлюбі більше 10 років (Хсер. $=-0,13, \sigma=$ 0,48). Прояв ревнощів у конфліктах найбільш позитивно та активно демонструють, ті хто живе у шлюбі більше 10 років (Хсер. $=0,58, \sigma=0,55$ ), менш інтенсивно група зі стажем подружнього життя 3-10 років (Хсер. $=0,3, \sigma=0,66)$ та не інтенсивно група зі стажем до 3 років (Хсер. $=0,09, \sigma=0,63$ ). 


\section{Питання психології}

Щодо інших шкал, то тут відмінностей на статистичному рівні не спостерігається. В той же час прагнення до автономії $\mathrm{y}$ конфліктних ситуаціях найбільш активно та негативно проявляється у тих, хто має подружній стаж до 3 років, домінування та ставлення до грошей найбільш позитивно та активно демонструється тими, хто живе у шлюбі від 3 до років.

Отже, у конфліктних ситуаціях найбільш активно та позитивно вибудовують відносини 3 родичами $\mathrm{i}$ друзями та домінують ті, хто має стаж подружнього життя 3-10 років; у питаннях, що пов'язані з вихованням дітей ті, хто у подружніх стосунках до 3 років, у прояві ревнощів, ті, хто живе у шлюбі більше 10 років. Найбільш негативно та активно виявляють автономію у конфліктах, ті, хто живе у шлюбі від 3 до 10 років та при порушенні рольових очікувань ті, хто має стаж сімейного життя до 3 років.

Особливості стосунків між членами сім'ї, особливості особистісного росту та управління сімейною системою ми визначили за методикою «Шкала сімейного оточення». До показників стосунки між членами сім’і відносяться згуртованість, експресивність та конфлікт. До показників особистісного росту - незалежність, орієнтація на досягнення, на активний відпочинок, інтелектуально-культурна орієнтація та морально-етичні аспекти. До управління сімейною системою відносять організація та контроль. Отримані дані представлено на рисунку 3 .

Експресивність у стосунках між членами сім'ї найсильніше проявляється в групі тих, хто живе подружнім життям більше 10 років (Xсер. $=5,33, \sigma=1,52)$, а найслабше у групі 3-10 років сімейного життя (Хсер. $=4,20, \sigma=0,89)$, ці відмінності зафіксовано на статистично значимому рівні. Щодо інших шкал даного блоку, то середні значення згуртованості у групах не мають значних відмінностей, конфлікту найменші у групі зі стажем подружнього життя більше 10 років.

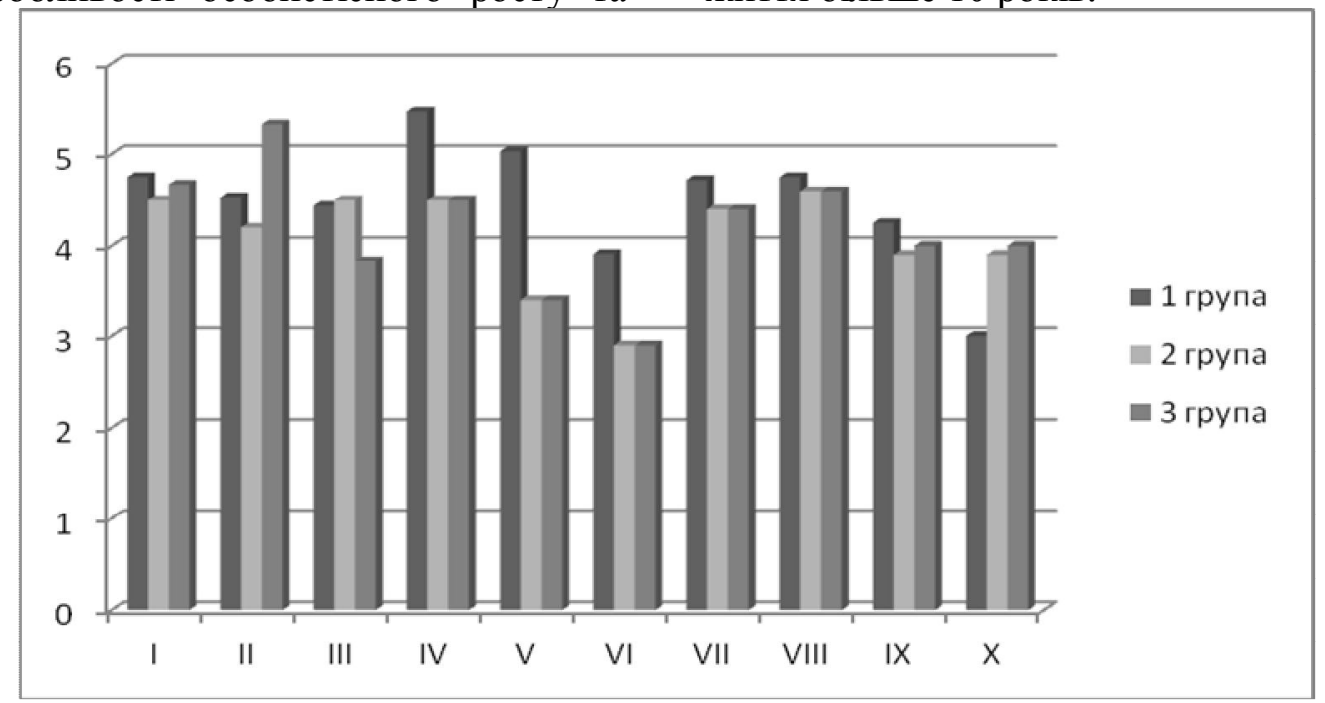

Рис. 3. Результати методики «Шкала сімейного оточення».

Примітка:

1. шкали: I - згуртованість, II - експресивність, III - конфлікт, IV - незалежність, V - орієнтація на досягнення, VI - інтелектуально-культурна орієнтація, VII - орієнтація на активний відпочинок, VIII - морально-етичні аспекти, IX - організація, X - контроль.

2. стаж подружнього життя: 1 група - до 3-ох років, 2 група - 3-10 років, 3 група - більше 10 років.

На особистісний ріст найбільше спрямовані ті досліджувані, що стаж подружнього життя мають до 3-ох років. Так, за шкалою «орієнтація на досягнення» середні значення мають наступну величину - Хсер. $=5,03, \sigma=1,09$; «інтелектуальнокультурна орієнтація» - Хсер. $=3,91, \sigma=$ 1,78. Щодо інших груп, то середні значення $\epsilon$ нижчими, і рівними в обох групах. В той

же час вище середнє значення за шкалою «незалежність» у тих, хто стаж подружнього життя до 3-ох років (Xсер. $=5,47, \sigma=1,97$ ); середні значення шкал «орієнтація на активний відпочинок» та «морально-етичні аспекти» в усіх груп є майже рівними.

Стосовно управління сімейною системою, то відмінностей на статистичному рівні не відмічається. Однак 


\section{Питання психології}

за шкалою «організація» середні значення є вищими в групі зі стажем подружнього життя до 3-ох років (Хсер. $=4,25, \sigma=1,78$ ).

Отже, експресивність у стосунках між членами сім'ї підвищується зі стажем подружнього життя, (найвищі показники у групі, що проживають разом більше 10 років. Найбілыш спрямованими на особистісний ріст через орієнтацію на досягнення та інтелектуально-культурну орієнтацію $є$ група опитаних, що мають стаж подружнього життя до 3 років; з віком актуальність особистісного росту знижується. Управління та контроль сімейною системою збільшується зі збільшенням стажу подружнього життя.

Ціннісні орієнтації особистості в реальних умовах життєдіяльності (приємне проведення часу, відпочинку; високий матеріальний добробут; пошук і насолода прекрасним; допомога і милосердя до інших людей; любов; пізнання нового у світі, природі, людині; високий соціальний статус i управління людьми; пізнання i повага людей та вплив на оточуючих; соціальна активність для досягнення позитивних змін у суспільстві; спілкування; здоров'я) досліджено за методикою «Діагностика реальної структури ціннісних орієнтацій особистості С.С. Бубнова». Згідно інтерпретації методики, за кожним видом цінностей опитувані можуть мати 6 балів. Чим більше число цінності, тим сильніше проявляється цінність в особистості. В результаті обробки отриманих даних ми змогли оцінити прояв цінностей у всіх групах опитаних залежно від їхнього стажу подружнього життя. Отримані дані представлено на рисунку 4.

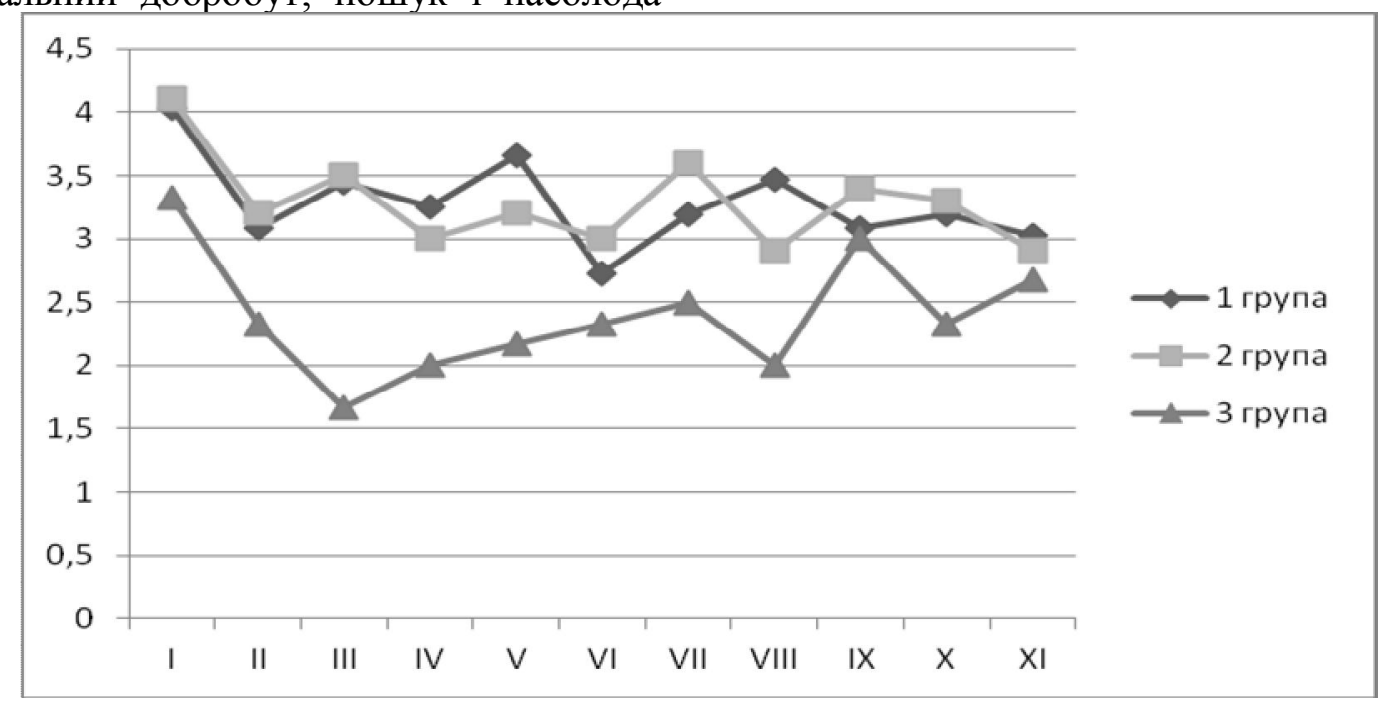

Рис 4. Результати методики «Діагностика реальної структури ціннісних орієнтацій особистості С.С. Бубнова»

Примітка:

1. цінності: I - приємне проведення часу, відпочинку, II - високий матеріальний добробут, III пошук і насолода прекрасним, IV - допомога і милосердя до інших людей, V - любов, VI - пізнання нового у світі, природі, людині, VII - високий соціальний статус і управління людьми, VIII - пізнання і повага людей та вплив на оточуючих, IX - соціальна активність для досягнення позитивних змін у суспільстві, X - спілкування, XI - здоров'я.

2. стаж подружнього життя: 1 група - до 3-ох років, 2 група - 3-10 років, 3 група - більше 10 років.

За 8 ціннісними орієнтаціями зміни відбуваються на статистично значимому рівні. Так, такі цінності, як «допомога i милосердя до інших людей», «любов», «пізнання i повага людей та вплив на оточуючих» $\epsilon$ найбільш значимими у групі досліджуваних, що стаж сімейного життя до 3-ох, у наступній групі менш значимим i найменш $є$ у групі тих, хто має стаж подружнього життя більше 10 років. А такі цінності, як: «приємне проведення часу,

відпочинку», «високий матеріальний добробут», «пошук і насолода прекрасним», «високий соціальний статус i управління людьми», «спілкування» найвищими $є$ у групі досліджуваних, що мають стаж подружнього життя від 3 до 10 років, у групі молодих сімей вищі і значно нижчими вони виявилися у групі тих, хто живе подружнім життям більше 10 років. Найбільше проявляється у всіх групах така цінність, як: «приємне проведення часу, відпочинку». 


\section{Питання психології}

Цінності, які є основою подружнього життя та визначають особливості спілкування змінюються зі стажем подружнього життя. Такі цінності, як «допомога і милосердя до інших людей» (Хсер. $=3,25, \sigma=1,32)$, «любов» (Хсер. $=$ $3,66, \sigma=0,90)$ та «пізнання і повага людей та вплив на оточуючих» $($ Хсер. $=3,47, \sigma=0,84)$ найбільш виражені у групі, що мають стаж подружнього життя до 3-ох років; «високий соціальний статус i управління людьми» (Xсер. $=3,60, \sigma=1,13)$, «соціальна активність для досягнення позитивних змін у суспільстві» (Хсер. $=3,40, \sigma=1,13$ ) та «спілкування» (Хсер. $=3,30, \sigma=1,02$ ) у групі опитаних з подружнім стажем від 3 до 10 років. Щодо групи досліджуваних, які проживають у шлюбі більше 10 років, то найменш важливими у них $є$ такі цінності, як: «пошук і насолода прекрасним» (Xсер. = $1,67, \sigma=0,76)$, «допомога і милосердя до інших людей» (Хсер. $=2,00, \sigma=0,59)$, «любов» $($ Хсер. $=2,17, \sigma=0,38)$ та «пізнання i повага людей та вплив на оточуючих» (Хсер. $=2,00, \sigma=1,18)$. Отримані дані в останній зазначеній групі для нас виявилися дещо неочікуваними. Особливо це стосувалося таких цінностей, як «допомога i милосердя до інших людей» та «пізнання і повага людей та вплив на оточуючих».

Отже, цінності змінюються зі стажем подружнього життя. Допомога, милосердя до інших людей, любов, пізнання і повага людей, вплив на оточуючих $\epsilon$ найбільш вираженими у молодого подружжя; високий соціальний статус, управління людьми, соціальна активність для досягнення позитивних змін у суспільстві, спілкування $\epsilon$ важливими для тих, хто має стаж подружнього життя 3-10 років. Найменш важливими у групі досліджуваних, які проживають у шлюбі більше 10 років є: пошук i насолода прекрасним, допомога i милосердя до інших людей, любов», пізнання i повага людей та вплив на оточуючих.

Наступним етапом нашого опису буде результати кореляційного аналізу. Кореляційний аналіз було здійснено для визначення міри взаємозв'язку між різними шкалами методик, що були застосовані у процесі дослідження.

Оскільки задоволеність шлюбом $\epsilon$ i наслідком складених міжособистісних взаємин, і причиною їх проаналізуємо отримані кореляційні зв'язки між задоволеністю шлюбом та іншими показниками. Представляти їх будемо у кожній групі залежно від стажу подружнього життя.

Кореляційний аналіз у групі зі стажем подружнього життя до 3-ох років показав, що задоволеність сімейним життям має прямий високого рівня кореляційний зв'язок з експресивністю ( $\mathrm{r}=0,709$, при $p=0)$, тобто підвищенням згуртованості підвищується експресивність, i, навпаки. Також 3 задоволеністю подружнім життям корелюють на помітних прямих шкали: допомога і милосердя до інших людей $(\mathrm{r}=$ $0,697$, при $p=0)$ та конфлікт ( $\mathrm{r}=0,525$, при $p$ $=0,002)$, тобто задоволеність сімейним життям підвищується із бажанням допомагати людям, проявляти милосердя та конфліктами. Також помірні прямі та зворотні взаємозв'язки помічено між задоволеністю шлюбом та шкалами: пізнання нового у світі, природі, людині (r = $0,457$, при $p=0,009)$, Згуртованість $(\mathrm{r}=$ $0,429$, при $p=0,014)$, відносини з родичами i друзями $(\mathrm{r}=-0,423$, при $p=0,016)$, високий соціальний статус i управління $(\mathrm{r}=0,420$, при $p=0,017)$, домінування одним із подружжя $(\mathrm{r}=-0,402$, при $p=0,023)$, пошук i насолода прекрасним ( $\mathrm{r}=0,392$, при $p=$ 0,026), приємне проведення часу, відпочинку ( $\mathrm{r}=0,354$, при $p=0,047)$ та стажем сімейного життя $(\mathrm{r}=-0,351$, при $p=$ 0,049). Тобто, з підвищенням задоволеністю сімейним життям підвищується пізнання нового у світі, природі, людині, згуртованість, високий соціальний статус i управління, пошук і насолода прекрасним, приємне проведення часу, відпочинку, a iз відносинами 3 родичами $\mathrm{i}$ друзями, домінуванням одним із подружжя та стажем сімейного життя, навпаки, знижується.

Отже, у групі досліджуваних, що мають стаж сімейного життя до 3-ох років задоволеність залежить сімейного оточення, від спілкування та взаємодії у конфлікті, від ціннісних орієнтацій.

Щодо групи зі стажем подружнього життя від 3 до 10 років, то задоволеність сімейним життям у них має прямий та зворотній високого рівня кореляційні зв'язки 3 домінування одним із подружжя $(\mathrm{r}=0,752$, при $p=0)$, згуртованістю $(\mathrm{r}=-0,717$, при $p=$ $0)$ тобто підвищенням згуртованості підвищується рівень домінування одним із подружжя та знижується згуртованість, i, навпаки. 


\section{Питання психології}

Також 3 задоволеністю подружнім життям корелюють на помітних прямих шкали: пізнання нового у світі, природі, людині $(\mathrm{r}=0,578$, при $p=0,001)$ та високий соціальний статус і управління людьми $(\mathrm{r}=$ $0,567$, при $p=0,001)$, тобто задоволеність сімейним життям підвищується із бажанням пізнати нове у світі, природі, людині та високим соціальним статусом та управління людьми. Також помірні прямі та зворотні взаємозв'язки помічено між задоволеністю шлюбом та шкалами: любов $(\mathrm{r}=0,456$, при $p$ $=0,011)$, орієнтація на активний відпочинок $(\mathrm{r}=0,454$, при $p=0,012)$, експресивність $(\mathrm{r}=$ $-0,426$, при $p=0,019)$, приємне проведення часу, відпочинку $(\mathrm{r}=0,420$, при $p=0,017)$, автономія $(\mathrm{r}=-0,397$, при $p=0,030)$, соціальна активність для досягнення позитивних змін у суспільстві $(\mathrm{r}=0,378$, при $p=0,039)$. Тобто, 3 підвищенням задоволеністю сімейним життям підвищується любов, орієнтація на активний відпочинок, приємне проведення часу, відпочинку та соціальна активність для досягнення позитивних змін у суспільстві, а 3 автономією та експресивністю, навпаки, знижується.

Отже, так само як i у попередніх досліджуваних у даній групі досліджуваних, що мають стаж сімейного життя від 3 до 10 років задоволеність залежить сімейного оточення, від спілкування та взаємодії у конфлікті, від ціннісних орієнтацій.

У групі зі стажем подружнього життя більше 10 років задоволеність сімейним життям має значну кількість кореляційних зв'язків. Так, прямі та зворотні високого рівня взаємозв'язки спостерігаються зі шкалами: відносини з родичами і друзями (r $=0,953$, при $p=0)$, стаж сімейного життя $(\mathrm{r}$ $=-0,885$, при $p=0$ ), орієнтація на активний відпочинок ( $\mathrm{r}=0,884$, при $p=0)$, автономія $(\mathrm{r}=0,872$, при $p=0)$, експресивність ( $\mathrm{r}=$ $0,781$, при $p=0)$, конфлікт ( $\mathrm{r}=-0,757$, при $p$ $=0)$, ставлення до грошей $(\mathrm{r}=0,718$, при $p=$ $0)$, допомога і милосердя до інших людей ( $\mathrm{r}$ $=0,717$, при $p=0$ ). Тобто 3 підвищенням згуртованості підвищуються показники рівня відносин 3 родичами i друзями, орієнтації на активний відпочинок, автономію, ставлення до грошей, допомоги і милосердя до інших людей, і навпаки. А також спостерігається зниження задоволеності подружнім життям зі збільшенням стажу сімейного життя, підвищенням

експресивності,

конфліктності, i, навпаки.

Також задоволеність подружнім життям має прямі та зворотні кореляції на помітному рівні 3 такими шкалами, як: неузгодженість норм поведінки $(\mathrm{r}=0,692$, при $p=0,000)$, пізнання і повага людей та вплив на оточуючих ( $\mathrm{r}=0,637$, при $p=$ $0,001)$, пошук i насолода прекрасним ( $\mathrm{r}=$ $0,637$, при $p=0,00)$, домінування одним із подружжя $(\mathrm{r}=0,623$, при $p=0,001)$, згуртованість $(\mathrm{r}=-0,613$, при $p=0,001)$, пізнання нового у світі, природі, людині ( $\mathrm{r}=$ $0,596$, при $p=0,001)$, питання, пов'язані $з$ вихованням дітей $(\mathrm{r}=0,592$, при $p=0,002)$, високий матеріальний добробут $(\mathrm{r}=0,591$, при $p=0,002)$, спілкування $(\mathrm{r}=0,569$, при $p$ $=0,004)$, соціальна активність для досягнення позитивних змін у суспільстві (r $=-0,557$, при $p=0,027)$. Тобто рівень задоволеності сімейним життя підвищується із узгодженістю норм поведінки, з підвищенням пізнання і поваги людей та впливу на оточуючих, з пошуком i насолодою прекрасним, із домінуванням одного із подружжя, пізнанням нового у світі, природі, людині, 3 високим матеріальним добробутом, спілкування, в той же час через зниження згуртованості, соціальної активності для досягнення позитивних змін у суспільстві.

Також помірні зворотні взаємозв'язки помічено між задоволеністю шлюбом та незалежністю ( $\mathrm{r}=-, 451$, при $p=0,027)$, морально-етичними аспектами $(\mathrm{r}=-0,413$, при $p=0,045)$. Тобто, 3 підвищенням задоволеністю сімейним життям знижується незалежність та морально-етичні аспекти, i, навпаки.

Отже, так само як і у попередніх групах досліджуваних у даній групі досліджуваних, що мають стаж сімейного життя більше 10 років задоволеність залежить сімейного оточення, від спілкування та взаємодії у конфлікті, від ціннісних орієнтацій. В той же час у них даних кореляційних зв'язків значно більше і ці взаємозалежності $\epsilon$ вищими за своєю значимістю.

\section{Висновки та перспективи подалыших досліджень.}

В результаті дослідження можемо зробити наступні висновки:

1. Найбільш благополучними є ті сім'і, які мають менший стаж подружнього життя. У подружніх пар, що проживають разом 310 років найвищий прояв довіри $\mathrm{y}$ 


\section{Питання психології}

спілкуванні, взаєморозумінні, схожості у поглядах та легкості у спілкуванні. У тих хто проживає разом більше 10 років найменше виявляється «терапевтичність стосунків».

2. Пари зі стажем подружнього життя до 3 років активно та позитивно налаштовані у процесі конфліктної взаємодії в питаннях виховання дітей та в процесі узгодження норм поведінки. Пари зі стажем 3-10 років краще вибудовують відносини 3 родичами, друзями та у визначенні домінування когось із пари, а при порушенні рольових очікувань налаштовані негативно та деструктивно. Тi, хто живе у шлюбі більше 10 років найменше конфліктують 3 приводу ревнощів.

3. Експресивність у стосунках між членами сім’і, управління та контроль сімейною системою підвищується зі стажем подружнього життя. 3 віком актуальність особистісного росту, орієнтація на досягнення та інтелектуально-культурна орієнтація знижується.

4. Цінності змінюються зі стажем подружнього життя. Допомога, милосердя до інших людей, любов, пізнання і повага людей, вплив на оточуючих $є$ найбільш вираженими у молодого подружжя; високий соціальний статус, управління людьми, соціальна активність для досягнення позитивних змін у суспільстві, спілкування $€$ важливими для тих, хто має стаж подружнього життя 3-10 років. Найменш важливими у групі досліджуваних, які проживають у шлюбі більше 10 років є: пошук i насолода прекрасним, допомога i милосердя до інших людей, любов», пізнання i повага людей та вплив на оточуючих.

5. У всіх групах досліджуваних задоволеність шлюбом залежить від особливостей сімейного оточення, від спілкування та взаємодії у конфлікті, від ціннісних орієнтацій. $\mathrm{y}$ парах досліджуваних зі значним стажем подружніх взаємовідносин кореляційні зв'язки є більш сильними та значимими.

Перспективу дослідження вбачаємо у виробленні рекомендацій для покращення сімейних взаємин та складанні консультативних програм для надання психологічної допомоги сімейним парам.

\section{Список використаних джерел}

1. Алешина Ю.Е. Индивидуальное и семейное психологическое консультирование. 2-е изд. М. : Независимая фирма «Класс», 2007. 208 с

2. Алешина Ю.Е., Гозман Л.Я., Дубровская Е.М. Социально-психологические методы исследования супружеских отношений. Спецпрактикум по социальной психологии. Изд-во МГУ, 1987. $120 \mathrm{c}$.

3. Андреева Т. В. Психология современной семьи : монографія. СПб. : Речь, 2005. 244 с.

4. Корольчук М.С. Психологія сімейних взаємин. К.: Ніка-центр, 2011. 296 с.

5. Помиткіна Л.В. Психологія сім'ї: навч. посіб. К.: Вид-во Нац. авіац. унту «НАУ-друк», 2010. 270 c.

6. Роджерс К. Брак и его альтернативы. Позитивная психология семейных отношений; пер. с англ. Е. Г. Разановой. М. : Этерна, 2006. 320 с. (Современная психология).

7. Карабанова О. А. Психология семейных отношений и основы семейного консультирования : учеб. пособие. М. : Гардарики, 2008. 320 с.

8. Пезешкиан Н. Тренинг семейных отношений. 33 и 1 форма партнерства; [пер. с нем.]. 3-е изд. М. : Институт позитивной психотерапии, 2009. 288 с.

\section{References}

1. Aleshina Yu.Ye. Individualnoe i semeynoe psikhologicheskoe konsultirovanie [Individual and family psychological counseling]. 2-e izd. M. : Nezavisimaya firma 〈Klass», 2007. 208 s. (in Russia)

2. Aleshina Yu.Ye., Gozman L.Ya., Dubrovskaya Ye.M. Sotsialno-psikhologicheskie metody issledovaniya supruzheskikh otnosheniy [Socio-psychological research methods of matrimonial relations]. Spetspraktikum po sotsialnoy psikhologii. Izd-vo MGU, 1987.120 s. (in Russia)

3. Andreeva T. V. Psikhologiya sovremennoy semi [Psychology of the modern family]: monografiya. $\mathrm{SPb}$. : Rech, 2005. 244 s. (in Russia)

4. Korolchuk M.S. Psykholohiia simeinykh vzaiemyn [Psychology of family relationships]. K.: Nikatsentr, 2011.296 s. (in Ukrainian)

5. Pomytkina L.V. Psykholohiia simi [Family psychology]: navch. posib. K.: Vyd-vo Nats. aviats. untu «NAU-druk», 2010.270 s. (in Ukrainian) 


\section{Питання психології}

6. Rodzhers K. Brak i ego alternativy. Pozitivnaya psikhologiya semeynykh otnosheniy [Marriage and its alternatives. Positive psychology of family relationships]; per. s angl. Ye. G. Razanovoy. M. : Eterna, 2006. 320 s. (Sovremennaya psikhologiya). (in Russia)

7. Karabanova O. A. Psikhologiya semeynykh otnosheniy i osnovy semeynogo konsultirovaniya [The psychology of family relationships and the basics of family counseling]: ucheb. posobie. M. : Gardariki, 2008. 320 s. (in Russia)

8. Pezeshkian N. Trening semeynykh otnosheniy. 33 i 1 forma partnerstva [Family relations training. 33 and 1 form of partnership]; [per. s nem.]. 3-e izd. M. : Institut pozitivnoy psikhoterapii, 2009. 288 s. (in Russia)

\section{Резюме}

Березовская Л. И. кандидат психологических наук, дочент, Национальный университет «Львівська політехніка»

Ямчук Т. Ю. кандидат психологических наук,

Мукачевский государственный университет.

\section{ПСИХОЛОГІЯ МІЖОСОБИСТІСНИХ ВЗАЕМИН ПОДРУЖНЬОЇ ПАРИ}

В статье представлено результать теоретического и эмпирического исследования межличностных взаимодействий семейной пары. Определено, что наиболее благополучными молодые семьи. Удовлетворенность браком зависит от особенностей семейного окружсения, от общения $и$ взаимодействия в конфликте, от иенностных ориентаций. В парах испьтуемых со значительным стажем супружеских отнотений кореляционные связи наиболее сильные и значимые.

Ключевые слова: межличностные отночения; супружеские пары; удовлетворенность браком; конфликтное взаимодействие; иенностные ориентаиии.

\section{Summary}

Berezovska L. I. Candidate of Psychological Sciences, Associate Professor Lviv Polytechnic National University

Yamchuk T. Y. Candidate of Psychological Sciences, Mukachevo State University

\section{PSYCHOLOGY OF INTERPERSONAL RELATIONSHIPS COUPLES}

Introduction. Psychological understanding of family relationships has theoretical and practical significance for the well-being and stability of family relationships, for providing psychological assistance to married couples.

Purpose. The aim of the article is to highlight the psychological features of interpersonal relationships of married couples with different lengths of family life.

Methods. Theoretical (literature analysis, generalization of theoretical data) and empirical (instrumental methods) research methods are used.

Originality. It was determined that the most successful are those families who have less experience of married life. Married couples living together for 3-10 years have the highest level of trust in communication, mutual understanding, similarity of views and ease of communication. Those who have lived together for more than 10 years have the least "therapeutic relationship".

Couples with up to 3 years of experience are actively and positively in the process of conflict interaction in raising children and in the process of agreeing on norms of behavior. Couples with 3-10 years of experience better build relationships with relatives, friends and in determining the dominance of one of the couple, and in violation of role expectations are negative and destructive. Those who have been married for more than 10 years have the least conflict over jealousy.

Expressiveness in family relationships, management and control of the family system increases with marital experience. With age, the relevance of personal growth, focus on achievements and intellectual and cultural orientation decreases.

Values change with the experience of married life. Help, compassion for other people, love, knowledge and respect for people, influence on others are most pronounced in a young couple; high social status, people management, social activity to achieve positive changes in society, communication are important for those who have 3-10 years of married life experience. The least important in the group of subjects who have been married for more than 10 years are: the search for and enjoyment of the beautiful, help and compassion for other people, love, knowledge and respect for people and influence on others.

In all groups of subjects, marital satisfaction depends on the characteristics of the family environment, on communication and interaction in conflict, on value orientations. In couples with long-term marital relationships, correlations are stronger and more significant.

Conclusion. We see the prospects of the research in the development of recommendations for improving family relationships and to compose counseling programs to provide psychological assistance to couples.

Key words:interpersonal relationships; couples; satisfaction with marriage; conflict interaction; value orientation. 